\title{
Erciyes Üniversitesi Tıp Fakültesi Birinci Sınıf Öğrencilerinin Sosyal Aktivitelere Katılma Durumlarının Değerlendirilmesi
}

\section{Assessment of Participation of First Year Students of Erciyes University Medical Faculty to Social Activities}

Alper Bulut, Zeynep Baykan, Melis Naçar

Erciyes Üniversitesi Tıp Fakültesi

\begin{abstract}
Anahtar Sözcükler:
öğrenci, tıp fakültesi, sosyal aktivite

Keywords:

student, medical faculty, social activity

Gönderilme Tarihi

Submitted:01.12.2017

Kabul Tarihi

Accepted: 08.05.2018
\end{abstract}

\section{ÖZET:}

Amaç: Sosyal aktiviteler, gençlerin derslerdeki başarılarında ve çevreyle ilişkilerinde büyük önem teşkil etmektedir. Hasta ile birebir iletişim kuracak geleceğin hekimleri için sosyal aktivitelerin önemi yadsınamaz. $\mathrm{Bu}$ çalışma kapsamında tıp fakültesi birinci sınıf öğrencilerinin sosyal aktivitelere katılma durumları değerlendirilmiştir.

Gereç ve Yöntem: Çalı̧̧ma Mayıs 2016'da yürütülmüş kesitsel tarama araştırmadır. Birinci sınıf öğrencilerinin tamamı çalışmaya dahil edilmiştir. Çalışmada yapılandırılmış bir anket formu kullanılmıştır. Anketin amacı açıklanmış, öğrencilerin onamları alınarak anketler dağıtılıp toplanmıştır. İstatistik analizde ki-kare kullanılmıştır. Araştırmada $\mathrm{p}<0,05$ istatistiksel olarak anlamlı kabul edilmiştir.

Bulgular: Öğrenciler ellerine geçen paranın yaklaşık \% 40 'ını sosyal aktivitelere ayırdıklarını ifade etmişlerdir. Öğrencilerin \%16,0'1 Kayseri'yi sosyal olanaklar açısından çok iyi/ iyi olarak, \%47,6's1 orta olarak, \%36,4'ü kötü/çok kötü olarak değerlendirmiştir. Öğrencilerin \%52,4'ü tıp fakültesinde olmanın sosyal aktivitelere katılımlarını etkilemediğini belirtmiştir. Öğrencilerin \%72,9'u günlük ortalama boş zamanlarının iki saatten fazla olduğunu söylemiştir. Öğrencilerin en çok katıldıkları sosyal aktivite arkadaşlarıyla birlikte (kafe, çay bahçesi vs) zaman geçirmekti.

Sonuç: Öğrencilerimizin büyük bir kısmının amaçlı ve aktif sosyal aktivitelere katılımı zayıftır.

\section{MAKALE KÜNYE BİLGISI}

- Bulut, A., Baykan, Z., \& Naçar M. (2018). Erciyes Üniversitesi Tıp Fakültesi Birinci Sınıf Öğrencilerinin Sosyal Aktivitelere Katılma Durumlarının Değerlendirilmesi. Tıp Eğitimi Dünyası, (17)52, 56-69. 


\section{ABSTRACT:}

Aim: Social activities are of great importance in young people's academic achievements and in relation with the environment. The importance of social activities for physicians who will communicate with the patient personally can't be denied. In this study, participation of first year medical students in social activities was evaluated.

Material method: This is a cross-sectional survey conducted in May 2016. All first year students were included. A structured questionnaire was used in the study. The purpose of the questionnaire was explained, their consent was taken and the questionnaires were distributed and collected. Chi-square was used for statistical analysis. In the study $p<0.05$ was considered statistically significant.

Results: Students stated that they allocate the $40 \%$ of their money to social activities. Kayseri is rated as very good/good in terms of social possibilities by $16.0 \%$, rated as moderate by $47.6 \%$ and rated as bad/very bad by $36.4 \%$ of the students. $52.4 \%$ of the students stated that being in medical faculty did not affect their participation in social activities. $72.9 \%$ of the students said that their daily average leisure time was more than two hours. The most common social activity among students was spending time with their friends (coffee shop, tea garden etc.).

Conclusion: A large part of our students are poorly engaged in purposeful and active social activities.

\section{GİRIŞ}

Sosyal aktivite, bireyin serbest zamanlarında doyum sağlamak amacıyla kendi isteğiyle yaptığı, zevk aldığı faaliyetlerdir (1). Aktif veya pasif olarak dâhil olunan bu aktiviteler, bireylerin toplumun içinde yer almalarına yardım ederek yaşamlarını güzelleştirmektedir. Bireyin özgüvenini pozitif yönde etkileyerek kişiliğinin şekillenmesinde rol oynamaktadır. Özellikle spor gibi bir sosyal aktivitenin kişinin üzerindeki stresin etkisini azalttığı, depresyonu engellediği, bağışıklık sistemini güçlendirdiği tespit edilmiştir. Aktif sosyal aktivitelere katılımın bilişsel fonksiyonları arttırarak akademik başarıyı da olumlu yönde etkilediği bilinmektedir (2-5).

İnsan, yaşamda deneyimlerle kendine yer edinmektedir. Deneyimlerin temelini de sosyal aktiviteler yapılandırmaktadır. Üniversite dönemi hayatın önemli süreçlerindendir. $\mathrm{Bu}$ süreç içindeki serbest zamanlarda yapılan sosyal aktivitelerle deneyimleri güçlü, karakterli, sağlam kişilikli bireylerin yetişmesine yardım etmekte; her pozitif davranıs bireyi mutluluğa ve başarıya taşımada bir adım daha ileriye götürmektedir (6). Serbest zamanın olumlu kullanımda ne kadar kişisel ve toplumsal gelişim sağlanabiliyorsa, olumsuz kullanımında da bunalım, kötü alışkanlıklar gibi istenmeyen sonuçlar ortaya çıkabilmektedir (7). Öğrencilerin serbest zamanlarını daha faydalı geçirebilme alışkanlıkları, sosyalleşme sürecinde içinde bulundukları eğitim kurumların özelliklerine göre de şekillenmektedir (8). Bu nedenle sağlanan imkânlar serbest zamanları değerlendirme biçimlerini büyük oranda etkilemektedir. $\mathrm{Bu}$ nedenle üniversiteler öğrencilerin formal eğitimleri dışındaki serbest zamanlarını en iyi şekilde değerlendirmeleri için yönlendirici rol üstlenmelidir.

Üniversite eğitimi yeni bir çevreye uyum, dersler, gelecekle ilgili endişeler gibi sebeplerle öğrencilerde anksiyete ve depresyon riskini attırmaktadır (9-12). Tip fakültesinde okuyan öğrencilerde depresyon ve anksiyete sıklığının yaygın olduğu da yapılan çalışmalarla gösterilmiştir. Tip eğitiminin uzun ve zorlu 
olması, eğitimdeki aşırı bilgi yükü ve aşırı çalışma zamanı ile öğrenilen bilgilerin mezuniyet sonrası insan sağlığıyla doğrudan ilgili olarak kullanılacak olması, yani bilginin tamamen doğru öğrenilmesi zorunluluğu bu yüksekliğe neden olabilecek sebeplerdir (1317). $\mathrm{Bu}$ nedenle tıp öğrencilerinin sosyal aktivitelere katılımlarının, biriken stresin getireceği etkilerden korunmada ve daha iyi birer hekim ve birey olmada onlara yardımcı olacağı açıktır.

$\mathrm{Bu}$ çalışmada Erciyes Üniversitesi Tıp Fakültesi birinci sınıf öğrencilerinin serbest zamanlarındaki sosyal aktivitelere katılma durumlarının değerlendirilmesi ve üniversitenin onlara bu açıdan sağladığı imkânlar hakkındaki düşüncelerinin belirlenmesi amaçlanmıştır.

\section{Materyal ve Metod}

$\mathrm{Bu}$ çalışma Erciyes Üniversitesi Tıp Fakültesi birinci sınıf öğrencilerinde Mayıs 2016'da yürütülmüştür. Araştırmanın yöntemi kesitsel taramadır. Birinci sınıf ögrrencilerinin tamamı $(\mathrm{N}=279)$ örneklem seçilmeden çalışmaya dahil edilmiş, 276 öğrenci araştırma anketini yanıtlamıştır. $\mathrm{Bu}$ öğrencilerin altısı anketinde soruların büyük bir bölümü doldurmadığ1 için anketleri çalışmadan çıkarılmıştır. Çalışmanın yürütülebilmesi için Tıp Fakültesi Dekanlığı'ndan ve Etik Kurul'dan gerekli izinler alınmıştır. Çalışmada araştırmacılar tarafından oluşturulan bir anket formu kullanılmıştır. Katılımcilara sosyo-demografik özelliklerini, sosyal aktivitelere katılım durumlarını ve üniversitenin imkânlarını değerlendirmeye yönelik sorular sorulmuştur. Sosyodemografik sorularda öğrencinin yaşı, cinsiyeti, uyruğu, kronik hastalik durumu, sosyal olanaklar ve bu olanaklara katılım açısından ili ve fakülteyi nasıl değerlendirdiği ile ilgili çeşitli sorular sorulmuştur. Öğrenciler önermeler şeklinde verilen (14 önerme) sosyal aktiviteye katılım durumlarını düzenli, ara sıra, nadiren veya hiç şeklinde derecelendirerek; bu sosyal aktivitelerle ilgili üniversitemizin imkânlarını yeterli bulma durumlarını ise yeterli, yetersiz, fikrim yok olarak işaretlemişlerdir. Anketler Mayıs ayı içinde tıbbi beceri dersi uygulaması sonrasında yapılmıştır. Tıbbi beceri dersi için sekiz gruba ayrılmış olan öğrencilere her grubun dersinden sonra anketin amacı araştırmacılar tarafından açıklanıp, onamları alınarak dağıtılıp toplanmıştır.

Veriler bilgisayara girildikten sonra yüzde ve sayısal değerlerle ifade edilmiştir. Sosyal aktiviteler araştırıcılar tarafından alan yazını incelendikten sonra aktiflik isteyen, "amaçlı faaliyetler" ve zaman geçirmeye yönelik "amaçları net olmayan faaliyetler" başlıkları altında sınıflandırılmıştır. Spor yapmak, sinemaya gitmek, okumak, müzik aleti çalmak, siyasal/dernek/kulüp/kurs etkinliklerine katılmak, beceri gerektiren el işi ve sanatla uğraşmak, gezilere katılmak "amaçlı aktiviteler" olarak sınıflandırılırken; arkadaşlarla zaman geçirmek ve internet kullanmak "amaçları net olmayan aktiviteler" olarak sınıflandırılmıştır.

Öğrencilerin sosyo-demografik özelliklerine göre düzenli olarak bir sosyal aktiviteye katılım durumlarının dağılımı değerlendirilirken kikare analizi kullanılmıştır. Araştırmada $\mathrm{p}<0.05$ istatistiksel olarak anlamlı kabul edilmiştir. Analizlerde SPSS 22.0 istatistik paket programı kullanılmıştır.

\section{Bulgular:}

Araştırma anketini dolduran $276 \quad(\% 98,9)$ öğrenciden 270'inin $(270 / 279=\% 96,8)$ yanıtları analiz edilmiştir. Öğrencilerin yaş ortalaması 19,0 $\pm 0,9$ yıldır. Öğrencilerin sosyo-demografik özelliklerinin dağılımı Tablo 1' de gösterilmiştir. Öğrenciler ellerine geçen paranın ortalama 
$\% 38,7 \pm 23,2$ 'sini sosyal aktivitelere ayırdıklarını ifade etmişlerdir. Öğrencilerin $\% 16,0^{\prime}{ }_{1}$ Kayseri'yi sosyal olanaklar açısından çok iyi/ iyi olarak, \%47,6's1 orta olarak, \%36,4'ü kötü/ çok kötü olarak değerlendirmiştir.

Öğrencilere "Okuduğunuz fakültenin sosyal aktivitelere katılım açısından durumunuzu etkileme biçimini nasıl değerlendiriyorsunuz?" diye sorulduğunda öğrencilerin \%17,6's1 tıp fakültesinde okuyor olmanın sosyal aktivitelere katılımlarını iyi yönde etkilediğini, \%52,4'ü etkilemediğini, \%29,2'si ise kısıtladığını belirtmiş̧iir. "Günlük ders dışı zamanınızın sosyal aktiviteler için nasıl olduğunu düşünüyorsunuz?" diye sorulduğunda öğrencilerin \%31,6's1 günlük ders dış1 zamanlarının sosyal aktiviteler için yeterli, $\% 36,8$ 'i yetersiz olduğunu düşünürken $\% 31$,6's1 kararsız olduğunu belirtmiştir. Öğrencilerin $\% 27,1$ 'i günlük ortalama boş zamanlarının iki saat ve altında olduğunu söylerken \%72,9'u iki saatten fazla olduğunu söylemiştir.

Öğrencilerin sosyal aktivitelere katılma durumlarının dağı̆lımı Tablo II' de gösterilmiştir. Öğrencilerin \%32,6’s1 (88 kişi) çalışmada belirtilen "amaçlı aktivitelerden" birini bile düzenli yapmadığını belirtmiştir.

Öğrencilerin bazı özelliklerine göre düzenli olarak katıldıklarını belirttikleri sosyal aktivitelerin dağılımı Tablo III' de gösterilmiştir. Öğrencilerin amaçlı aktivitelerle ilgili üniversitemizin imkânlarını yeterli bulma durumlarının dağılımı Tablo IV' de gösterilmiştir.

\section{Tartışma}

Günümüzde serbest zamanı değerlendirme bir yaşam biçimi halini almış ve serbest zaman aktivitelerinin artması ve yelpazesinin genişletilmesi için çeşitli program ve projelerin üretilmesi bir zorunluluk olmuştur. Yapılan aktivitelerin, yaşam biçimini etkileyen çabaları da içermesi, onların toplumun içinde yer alan bireyler olmasına yardım etmesi ve birlikte yaşamı güzelleştirmesi beklenmektedir (18). Etkin, yaratıcı ve olumlu bir biçimde değerlendirilen zaman bireylerin toplumsal statülerini de arttırmaktadır (19). Bu nedenle günümüz çağdaş üniversite süreci içinde eğitim ve serbest zaman etkinlikleri kesinlikle ayrı düşünülmemeli aksine eğitimin bir parçası sayılarak, işlevsel bir araç olarak kullanılmalıdır. Böylece bu araç, verimliliğin anahtarı olduğu gibi öğrencilerin fiziksel, toplumsal ve psikolojik gelişimi için de bir taban oluşturacaktır. Kaldı ki bu etkinlikler örgencilerin stres ve gerginliğini gidermek için firsatlar da sağlamaktadır. Yapılan bu çalışmada tıp fakültesi birinci sınıf öğrencilerinin yaklaşık üçte biri henüz başladıkları tıp fakültesinde olmanın sosyal aktivitelere katılımlarını kısıtladığını belirtmiştir. Yerleşkedeki etkinlikler öğrencilerin daha sonraki iş yaşamlarında karşılaşacakları iş ve serbest zaman arasında arzulanan dengeyi sağlamalarına yardımcı olabileceği gibi, öğrencilere yeni kazanımlar sağlayarak üniversite döneminden sonra yeni iş olanakları da sunabilmektedir (20). Henüz çalışma hayatı içinde yerini almamış, ailesine ekonomik bağımlılığı devam eden gençlerin harçlıklarının çok az bir bölümünü sosyal aktivitelere harcadıkları bilinmektedir (21). Çalışmamızda da benzer bir sonuç bulunmuştur. Ekonomik durumunu orta/kötü/ çok kötü olarak belirten öğrencilerin sosyal aktivitelere katılımları da kısıtlanmaktadır. Üniversitelerin bu nedenle sağlayabilecekleri ücretsiz sosyal olanaklar daha da önem kazanmaktadır.

Kentler, birbirine benzemeyen yaşam biçimlerine sahip insanların aynı yerleşim alanında, diğer yaşam biçimlerini kabullenerek yaşayabildiği mekânlardır. Bireyi topum 
yaşamında ön plana çıkartan kentler sunduğu olanaklarla bireyin gelişimini desteklemekte ve yönlendirmektedir (1). Bu açıdan bakıldığında araştırmaya katılan öğrencilerin \%84.0'ının Kayseri'yi sosyal olanaklar açısından orta/ kötü olarak nitelendirdikleri görülmektedir. Üniversite öğrencilerinin serbest zaman davranış eğilimlerinin, üniversite öncesi geçmiş yaşamlarında sahip oldukları eğilimlerden ziyade öğrenim gördükleri kentin kaynaklarının taşıdığı özelliklerin etkisiyle şekillendiği düşünüldüğünde Kayseri'nin sosyal olanaklarının yetersizliği ve/veya var olan olanakların yeterince tanıtılmadığı düşünülmektedir. Öğrencilerin \%60,4'ünün şehir dışından geldiği de dikkate alınarak Kayseri'deki sosyal imkanların tanıtımının üniversite/fakültede geliştirilmesi gerektiği görülmektedir.

Öğrencilerimizde amaçları net olmayan sosyal aktivitelere olan katılımın, amaçlı aktivitelere katılıma göre çok daha yüksek olduğu görülmektedir. Araştırmaya katılan öğrencilerin \%32,6's1 amaçlı aktivitelerden birini bile düzenli olarak yapmamaktadır. $\mathrm{Bu}$ sonuç üniversite öğrencilerinin serbest zamanlarını değerlendirme tercihlerini inceleyen çalışmalarla benzerlik göstermektedir (22-23). Çalışmalar öğrencilerin aktif katılımın söz konusu olabileceği alanlarından çok pasif katılımın söz konusu olduğu mekânlarda vakit geçirdiklerini desteklemektedir. Öğrencilerin aktif ve belirli bir amacı olan aktiviteler yerine pasif ve amacı belli olmayan aktivitelere yönelmesinde; aktif katılımlı bir yaşamın tanımlanmaması, kişilik, kültür, aile ve çevresindeki örnekler, fakültelerde ağır ders programlarının olması, serbest zamanın yetersiz olması, aktivite imkânlarının yetersiz olması, ekonomik durumunun iyi olmaması gibi nedenler olabilir (7). Çalışmamızda da öğrencilerin yaklaşık \%40'ının günlük ders dışı zamanlarının sosyal aktiviteleri için yetersiz olduğunu düşündüğü görülmektedir. Beraberinde yarıdan fazlası ekonomik durumunu orta/kötü/çok kötü olarak sınıflamaktadır. Ve yarıdan fazla üniversitenin amaçlı aktiviteler için imkânlarını yeterli bulmamaktadır. Özellikle el işi sanatları ve müzik aleti çalma aktivitelerindeki yetersizlik daha çok göze çarpmaktadır. $\mathrm{Bu}$ konuda üniversite ve fakültemizin üzerine düşen görev öncelikle el işi ve müzikle ilgili aktivitelerden başlayarak bütün aktivitelerin yerleşke içindeki imkanlarını arttırmaya çalışmak ve var olan imkanların tanıtımının daha iyi yapılmasını sağlamaktır.

Düzenli olarak yapılan amaçlı aktiviteler içinde ilk iki aktivite 'Çeşitli alanlarda kitap okuma' ve 'Spor yapma' olmuştur. Ancak bunları bile öğrencilerin sadece dörtte biri düzenli olarak yapmaktadır. Müzik aleti çalma, el işi sanatlarıyla uğraşma, siyasal aktivitelere, gezilere ve kişisel gelişimi sağlayacak kurslara katılma gibi aktiviteleri düzenli olarak yapanların sayısı \%10'u bile geçememiştir. Yağmur'un 2014-15 y1lında Kayseri'de turizm eğitimi alan öğrencilerde yürüttüğü çalışma da benzer bir sonuç alınmıştır (24). Amaçlı aktivitelere katılımın bu kadar düşük olmasının sebepleri araştırılmalıdır.

Kitap okumanın bireye getirdiği yararlar ortadadır. Okuma, çağdaş olmanın ölçütlerinden birisidir (25). Sadece yeni bir şeyler öğrenmek için değil, bulunduğumuz dünyaya daha kapsamlı bir şekilde bakmak için de önemlidir (26). Çağdaş, yaratıc1, yapıcı ve özgür düşünceye sahip, üretken, eleştirel bakan bireylerden oluşan bir toplum olmak okuma bilinci aşılanmış bireylerle mümkündür. Bireyin yaşam boyu öğrenen bir kişi olabilmesi için okuma eylemini kendinde ömür boyu düzenli olarak yaşatması gerekmektedir (27). Çalışmamızda 
düzenli olarak dergi, gazete okuyanların oranı $\% 17$, roman okuyanların oranı $\% 20$ ve çeşitli alanlarda kitap okuyanların oranı \%27'dir. Hiç okumayanların oranı ise sırası ile \%14,7, $\% 18,1$ ve $\% 13,2$ olarak bulunmuştur. Yiğit ve arkadaşlarının çalışmasında hemşirelik öğrencilerinin \%89,6'sının kitap okuduğu belirlenmiştir (28). Kartal'ın 2012 yılındaki çalışmasında sık sık kitap okuduğu belirtenlerin oranı \%20,7'dir (8). Tip fakültesinde okuyan öğrenciler ileride topluma model olmaya adaydırlar fakat tıp öğrencilerinde bile bunca getirisine rağmen kitap okuma alışkanlığının bu denli düşük olması üzücü bir durumdur. Üniversite kütüphaneleri öğrencilerin okuma alışkanlıklarını destekleyecek programlara sahip olmalıdır. Öğrenciler yeni ve popüler yayınlar konusunda bilgilendirilmeli ve doğru kaynaklara yönlendirilmelidir (29). Bu çalışmada öğrencilerin yarısından fazlasının okul kütüphanesindeki imkânlarla ilgili fikri olmadığı görülmüştür. $\mathrm{Bu}$ da kütüphaneye gitmemiş olduklarını işaret etmektedir. Odabaş'ın çalışması da üniversitede kütüphaneye gitmeyen önemli bir öğrenci kitlesi bulunmakta olduğunu göstermiştir (27).

Öğrencilerin düzenli olarak katıldıkları sosyal aktiviteleri cinsiyetlerine göre değerlendirdiğimizde spor yapma, roman okuma ve interneti sosyal amaçlı kullanma aktivitelerinde cinsiyetler arasinda anlamlı fark bulunmuştur. Tip fakültesi birinci sınıf öğrencilerinin düzenli olarak spor yapma oranı $\% 26,9$ 'dur ve erkeklerde bu oran kızlardan daha fazladır. Üniversite öğrencilerinde yapılan çalışmalar benzer sonuçlar göstermektedir $(8,20,22,30)$. Roman okuma ve interneti sosyal amaçlı kullanma ise kız öğrencilerde fazladır. Arslan H.'nin çalışmasında da kız öğrencilerin roman, dergi, gazete ve çeşitli alanlarda kitap okudukları bulunmuştur, internette vakit geçirme arasında fark saptanmamıştır (22). Öğrencilerin kaldıkları yerlere göre de düzenli olarak yaptıkları aktiviteler farklılık göstermiştir. Evde kalanların düzenli olarak spor yapma oranı daha yüksek iken yurtta kalanların düzenli olarak roman okuma oranları daha yüksektir.

Sonuç olarak tıp fakültemizdeki öğrencilerin büyük bir kısmının amaçlı ve aktif sosyal aktivitelere katılımı zayıftır. Öğrencinin başarısını sadece formal başarı olmadı $\breve{g ̆}_{1}$ bilinmeli; serbest zamanlarını iyi değerlendiren bireylerin gerek iş gerek iş dışı hayatlarında daha başarılı, sağlıklı ve mutlu oldukları unutulmamalıdır. Bunun için üniversite öğrencileri bilinçlendirilmeli, üniversitelerdeki sosyal imkânlar arttırılmalı, eğitim sistemi içinde sosyal aktivitelere katılıma daha çok önem verilmelidir.

\section{Teşekkür:}

$\mathrm{Bu}$ araştırma konusunun belirlenmesi ve verilerinin toplanması sürecinde katk1 sağlayan Erciyes Üniversitesi Tıp Fakültesi öğrencilerimiz Numan Kalınlı, Hakan Laçin, Mehmet İrşat Şahin, Berra Turan, Ayşe Sena Oğuz, Burak Emiroğlu, Mevlüt Demirkıran, Hasan Demir ve Yunus Canbaz'a teşekkür ederiz.

\section{KAYNAKLAR}

1.Aslan K, Aslan N. Boş zaman değerlendirmede çevre faktörü. Ege Eğitim Dergisi 2001; 1(1): $1-12$.

2. Moraska A, Fleshner M. Voluntary physical activity prevents stres induced behavioral depression and anti-KLH antibody suppression. American Journal of Physiology, Regulatory, Integrative and Comparative Physiology 2001; 281: 484-490. 
3. Kwak L, Kremers SP, Bergman P, Ruiz JR, Rizzo NS, Sjostrom M. Association between physical activity, fitness and academic achievement. Journal of Pediatrics 2009; 155: 914-918.

4. Ağduman, F. Üniversite öğrencilerinin boş zaman motivasyon ve tatminlerinin incelenmesi. Yüksek Lisans Tezi, Atatürk Üniversitesi Sağlık Bilimleri Enstitüsü. 2014, Erzurum.

5. Yenal Y, İçigen TE. Üniversite öğrencilerinin sosyalleşme süreci ve rekreasyon faaliyetlerinin incelenmesi üzerine bir çalışma. Anatolia: Turizm Araştırmaları Dergisi 2016; 27(2): 227242.

6. Ağaoğlu YS. Türkiye'deki üniversitelerin rekreasyon programlarının geliştirilmesi. Doktora Tezi. Ondokuz Mayıs Üniversitesi Sağlık Bilimleri Enstitüsü Beden Eğitimi ve Spor Anabilim Dal1. 2002, Samsun.

7. Güçlü M. Gençlik döneminde boş zaman faaliyetlerinin yeri ve önemi. Gençlik Araştırmaları Dergisi 2013; 1(1): 158-169.

8. Kartal A, Çınar İÖ, Ağgön B. Sağlık yüksekokulu öğrencilerinin boş zamanlarını değerlendirme alışkanlıkları. Cumhuriyet Hemşirelik Dergisi 2012; 1: 1-9.

9. Bayram N, Bilgel N. The prevalence and socio-demographic correlations of depression, anxiety and stress among a group of university students. Soc Psychiatry Psychiatr Epidemiol 2008; 43: 667-672.

10. Ovuga E, Boardman J, Wasserman D. Undergraduate student mental health at Makerere University, Uganda. World Psychiatry 2006; 5(1): 51-52.
11. Stewart-Brown S, Evans J, Patterson J, Petersen S, Doll H, Balding J, Regis D. The health of students in institutes of higher education: an important and neglected public health problem? J Public Health Med 2000; 22(4): 492-499.

12. Nerdrum P, Rustøen T, Rønnestad MH. Student psychological distress: a psychometric study of 1750 Norwegian 1st-year undergraduate students. Scand J Edu Res 2006; 50(1): 95-109

13. Bíró E, Balajti I, Adány $\mathrm{R}$, Kosa K. Determinants of mental well-being in medical students. Soc Psychiatry Psychiatr Epidemiol 2010; 45(2): 253-258

14. Sarikaya O, Civaner M, Kalaca S. The anxieties of medical students related to clinical training. Int J Clin Pract, Nov 2006; 60(11): 1414-8.

15. Peng L, Zhang J, Li M, Li P, Zhang Y, Zuo $\mathrm{X}$ ve ark. Negative life events and mental health of Chinese medical students: The effect of resilience, personality and social support. Psychiatry Res 2012; 196(1): 138-41.

16. Baykan Z, M Naçar, Çetinkaya F. Depression, anxiety, and stress among last-year students at erciyes university medical school. Academic Psychiatry 2012; 6(1):64-65.

17. Öncü B, Şahin T, Özdemir S, Şahin C, Çakır K, Öcal E. Tıp fakültesi öğrencilerinde depresyon, anksiyete ve stres düzeyleri ve ilişkili etmenler. Kriz Dergisi 2013; 21: 1-10.

18. Kelly J.R. Leisure. Erişim Tarihi: 11.09.2017 Available from: https:/www.sagamorepub.com/ files/lookinside/215/leisure-look-inside.pdf. 
19. Tezcan M. Boş zamanların değerlendirilmesi sorununun sosyolojik ve eğitimsel yönleri. Ankara Üniversitesi Eğitim Bilimleri Fakültesi Dergisi 1978; 11(1): 165-179.

20. Hacıcaferoğlu S, Gündoğu C, Hacıcaferoğlu B. Üniversite öğrencilerinin spor tesislerine ve organizasyonlarına karşı düşüncelerinin değerlendirilmesi (İnönü Üniversitesi Örneği). Spor ve Performans Araştırmaları Dergisi 2012; 3(1): 42-51.

21. Ersoy S, Güldemir O. Üniversite öğrencilerinin boş zamanlarını değerlendirme faaliyetlerinin sosyoekonomik boyutu üzerine bir inceleme. XVII. Ulusal Eğitim Bilimleri Kongresi. 1-3 Eylül 2008. Sakarya.

22. Arslan H. Üniversite öğrencilerinin boş zaman değerlendirme tercihleri: Çankırı Karatekin Üniversitesi örneği. Dumlupınar Üniversitesi Sosyal Bilimler Dergisi 2014; 40: 193-208.

23. Süzer M. Üniversite öğrencilerinin boş zamanlarını değerlendirme alışkanlıkları. Pamukkale Üniversitesi Eğitim Fakültesi Dergisi 2000; 8: 123-133.

24. Yağmur Y, İçigen ET. Üniversite öğrencilerinin sosyalleşme süreci ve rekreasyon faaliyetlerinin incelenmesi üzerine bir çalışma. Anatolia: Turizm Araştırmaları Dergisi 2016; 27(1): 227-242.

25. Gömleksiz, M.N. Geleceğin öğretmenlerinin kitap okumaya ilişkin görüşlerinin değerlendirilmesi (Frrat Üniversitesi Eğitim Fakültesi Örneği). Yüzüncü Y1l Üniversitesi Elektronik Eğitim Fakültesi Dergisi 2005; 1(1): $1-21$.
26. Binbaşığlu, H. A Tuna, H. Vocational school students" habit of reading about occupation as leisure activity. İnönü Üniversitesi Eğitim Fakültesi Dergisi 2015; 16(2): 1-16.

27. Odabaş H, Odabaş ZY, Polat C. Üniversite öğrencilerinin okuma alışkanlığı: Ankara Üniversitesi örneği. Bilgi Dünyas1 2008; 9(2): 431-465.

28. Yiğit R, Esenay F, Derebent E. Türkiye'de hemşirelik son sınıf öğrencilerinin profili. Cumhuriyet Üniversitesi HYO Dergisi 2007; 11(3): 1-12.

29. Elliot J. Academic libraries and extracurricular reading promotion. Reference \& User Services Quarterly 2007; 46(3): 34-43.

30. Yerlisu Lapa T, Ardahan F. Akdeniz üniversitesi öğrencilerinin serbest zaman etkinliklerine katılım nedenleri ve değerlendirme biçimleri. Spor Bilimleri Dergisi 2009; 20(4):132-144. 
Tablolar

Tablo I: Öğrencilerin Sosyodemografik Özelliklerinin Dağılımı

\begin{tabular}{|c|c|c|}
\hline Sosyodemografik özellikler & Sayı & $\%$ \\
\hline \multicolumn{3}{|l|}{ Yaş (n=269) } \\
\hline$\leq 18$ & 81 & 30,1 \\
\hline$>18$ & 188 & 69,9 \\
\hline \multicolumn{3}{|l|}{ Cinsiyet $(n=270)$} \\
\hline Erkek & 138 & 51,1 \\
\hline Kadın & 132 & 48,9 \\
\hline \multicolumn{3}{|l|}{ Uyruk (n=270) } \\
\hline TC vatandaşı & 256 & 94,8 \\
\hline Diğer & 14 & 5,2 \\
\hline \multicolumn{3}{|l|}{ Medeni Durum (n=268) } \\
\hline Bekar & 266 & 99,3 \\
\hline Evli & 2 & 0,7 \\
\hline \multicolumn{3}{|l|}{$\begin{array}{l}\text { Yaşamın büyük bölümünü nerede } \\
\text { geçirdiği }(n=267)\end{array}$} \\
\hline İl merkezi & 206 & 77,2 \\
\hline İlçe & 51 & 19,1 \\
\hline Köy/Kasaba & 10 & 3,7 \\
\hline \multicolumn{3}{|l|}{$\begin{array}{l}\text { Okul dışında bir işte çalışma durumu } \\
(\mathrm{n}=269)\end{array}$} \\
\hline Evet & 3 & 1,1 \\
\hline Hayır & 266 & 98,9 \\
\hline \multicolumn{3}{|l|}{ Kaldığı yer (n=270) } \\
\hline Aile yanı & 107 & 39,6 \\
\hline Yurt & 117 & 43,4 \\
\hline $\begin{array}{l}\text { Diğer (Öğrenci evi, yakınların yanı, } \\
\text { kendi evi) }\end{array}$ & 46 & 17,0 \\
\hline \multicolumn{3}{|l|}{ Kronik hastalık varlığı $(n=269)$} \\
\hline Yok & 257 & 95,5 \\
\hline Var & 12 & 4,5 \\
\hline \multicolumn{3}{|l|}{ Ekonomik Durum $(\mathrm{n}=\mathbf{2 7 0})$} \\
\hline Çok iyi/İyi & 127 & 47,0 \\
\hline Orta & 138 & 51,1 \\
\hline Kötü/Çok Kötü & 5 & 1,9 \\
\hline
\end{tabular}


Tablo II: Öğrencilerin Sosyal Aktivitelere Katılım Durumlarının Dağılımı (\%)

\begin{tabular}{|c|c|c|c|c|}
\hline & Düzenli & Ara & Nadiren & Hiç \\
\hline \multicolumn{5}{|l|}{ Amaçlı aktiviteler } \\
\hline Spor yaparım $(n=264)$ & 26,9 & 40,9 & 23,9 & 8,3 \\
\hline Sinemaya giderim $(\mathrm{n}=262)$ & 11,1 & 52,3 & 30,2 & 6,5 \\
\hline Dergi, gazete okurum $(\mathrm{n}=265)$ & 17,0 & 34,3 & 34,0 & 14,7 \\
\hline Roman okurum $(\mathrm{n}=265)$ & 20,0 & 36,2 & 25,7 & 18,1 \\
\hline Çeşitli alanlarda kitap okurum $(\mathrm{n}=266)$ & 26,7 & 34,2 & 25,9 & 13,2 \\
\hline $\begin{array}{l}\text { Canlı ( konser, panel, şiir dinletisi, tiyatro, spor } \\
\text { müsabakaları vb.) aktiviteleri izlerim }(\mathrm{n}=266)\end{array}$ & 8,6 & 33,8 & 45,5 & 12,1 \\
\hline $\begin{array}{l}\text { Bir müzik aleti çalarım, solo, koro, orkestraya katılırım } \\
(\mathrm{n}=264)\end{array}$ & 7,6 & 8,7 & 13,6 & 70,1 \\
\hline $\begin{array}{l}\text { Siyasal etkinliklerde bulunurum (siyasal toplantı vs) } \\
(\mathrm{n}=261)\end{array}$ & 4,6 & 8,4 & 17,2 & 69,8 \\
\hline Beceri gerektiren el işi ve sanatla uğraşırım $(n=263)$ & 7,2 & 20,2 & 30,4 & 42,2 \\
\hline $\begin{array}{l}\text { Dernek ve kulüp faaliyetlerine(tema, öğrenci kulüpleri vb.) } \\
\text { katılırım (n=262) }\end{array}$ & 14,1 & 28,2 & 32,8 & 24,8 \\
\hline $\begin{array}{l}\text { Gezilere (doğa gezileri, şehir dışı geziler vb.) katılırım } \\
(\mathrm{n}=263)\end{array}$ & 7,6 & 42,2 & 40,3 & 9,9 \\
\hline Kişisel gelişimimi sağlayacak kurslara katılırım.(n=264) & 7,2 & 25,0 & 43,6 & 24,2 \\
\hline \multicolumn{5}{|l|}{ Amaçları net olmayan faaliyetler } \\
\hline $\begin{array}{l}\text { Arkadaşlarımla birlikte (kafe, çay bahçesi vs) zaman } \\
\text { geçiririm }(\mathrm{n}=266)\end{array}$ & 41,7 & 47,4 & 9,4 & 1,5 \\
\hline İnterneti sosyal amaçlı kullanırım $(\mathrm{n}=262)$ & 45,8 & 35,5 & 14,5 & 4,2 \\
\hline
\end{tabular}


Tablo III: Öğrencilerin Düzenli Olarak Katıldıklarını Belirttikleri Sosyal Aktivitelerin Cinsiyete, Kalınan Yere ve Ekonomik Duruma Göre Dağılımı*

\begin{tabular}{|c|c|c|c|}
\hline & \multicolumn{3}{|c|}{ Cinsiyet } \\
\hline & \multicolumn{2}{|l|}{ Erkek } & Kadın \\
\hline \multicolumn{4}{|c|}{ Amaçlı Aktiviteler } \\
\hline \multicolumn{4}{|c|}{ Spor yaparum } \\
\hline Evet & \multicolumn{2}{|l|}{39,9} & 12,1 \\
\hline \multirow[t]{2}{*}{ Hayır } & \multirow[t]{2}{*}{60,1} & & 87,9 \\
\hline & & \multicolumn{2}{|c|}{ Ki kare $=26,775 p<0,001$} \\
\hline \multicolumn{4}{|c|}{ Roman okurum } \\
\hline Evet & \multicolumn{2}{|l|}{13,0} & 26,5 \\
\hline \multirow[t]{2}{*}{ Hayır } & \multirow[t]{2}{*}{87,0} & & 73,5 \\
\hline & & \multicolumn{2}{|c|}{ Ki kare $=7,761 \mathrm{p}=0,005$} \\
\hline \multicolumn{4}{|c|}{ Amacı net olmayan aktiviteler } \\
\hline \multicolumn{4}{|c|}{ İnterneti sosyal amaçll kullanırım. } \\
\hline Evet & \multicolumn{2}{|l|}{37,0} & 52,3 \\
\hline \multirow[t]{4}{*}{ Hayır } & \multirow[t]{2}{*}{63,0} & & 47,7 \\
\hline & & \multicolumn{2}{|c|}{ Ki kare $=6,410 p=0,011$} \\
\hline & \multicolumn{3}{|c|}{ Kalınan Yer } \\
\hline & Aile yanı & Yurt & Diğer \\
\hline \multicolumn{4}{|c|}{ Amaçlı Aktiviteler } \\
\hline \multicolumn{4}{|c|}{ Spor yaparum } \\
\hline Evet & $29,9^{\mathrm{a}}$ & $18,8^{\mathrm{b}}$ & $37,0^{\mathrm{a}}$ \\
\hline Hayır & 70,1 & 81,2 & 63,0 \\
\hline
\end{tabular}




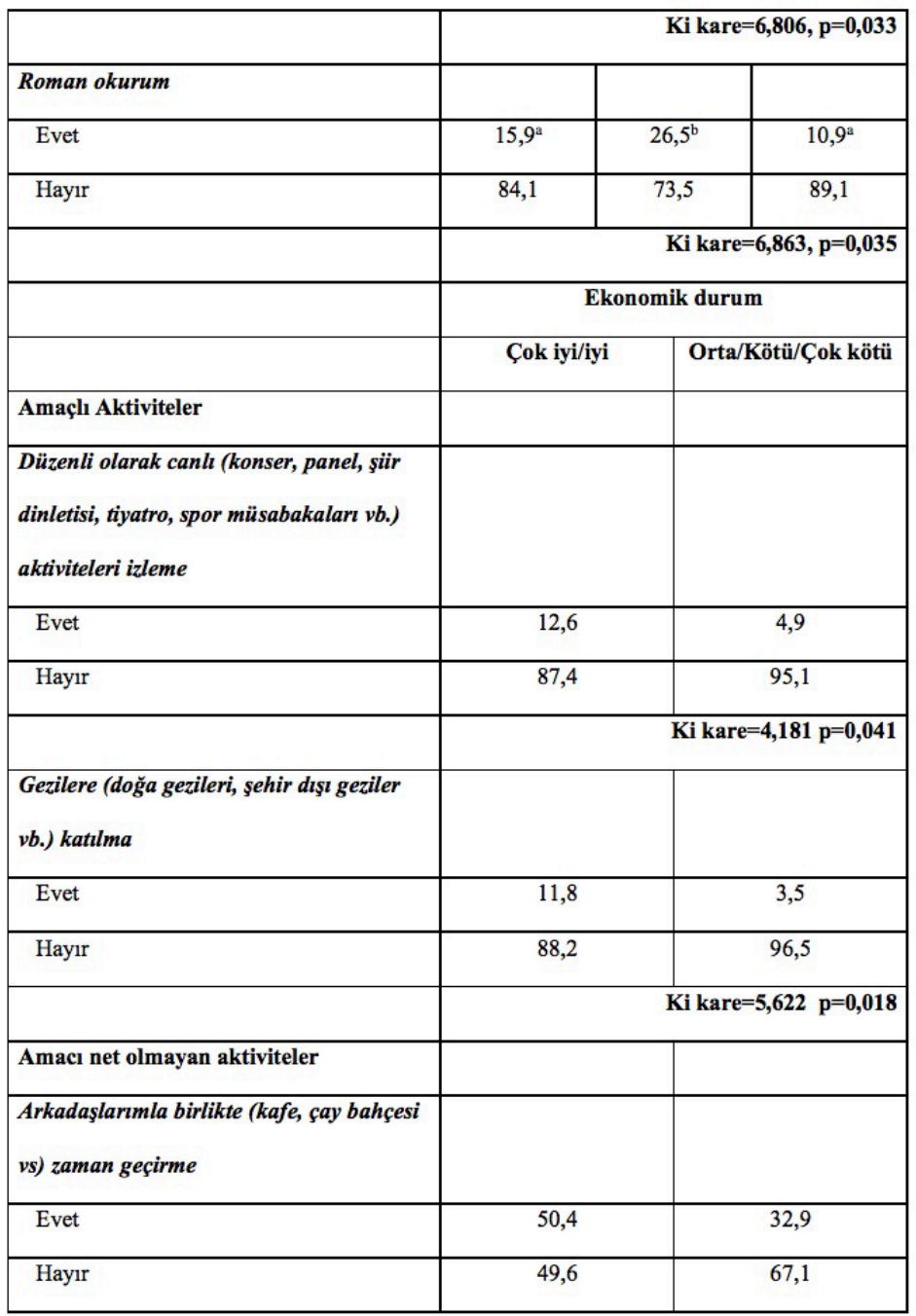




\begin{tabular}{|c|c|c|}
\hline & & Ki kare $=8,534 p=0,003$ \\
\hline & \multicolumn{2}{|c|}{ Yaşamın büyük bölümünü nerede geçirdiği } \\
\hline & İl merkezi & İlçe/kasaba/köy \\
\hline \multicolumn{3}{|l|}{ Amaçlı Aktiviteler } \\
\hline \multicolumn{3}{|l|}{ Sinemaya gitme } \\
\hline Evet & 13,1 & 3,1 \\
\hline Hayir & 86,9 & 96,9 \\
\hline & \multicolumn{2}{|r|}{ Ki kare $=4,087 \mathrm{p}=0,043$} \\
\hline \multicolumn{3}{|l|}{ Amacı net olmayan aktiviteler } \\
\hline \multicolumn{3}{|l|}{$\begin{array}{l}\text { Arkadaşlarımla birlikte (kafe, çay bahçesi } \\
\text { vs) zaman geçirme }\end{array}$} \\
\hline Evet & 45,1 & 28,1 \\
\hline Hayır & 54,9 & 71,9 \\
\hline & \multicolumn{2}{|r|}{ Ki kare $=5,843 \quad p=0,016$} \\
\hline
\end{tabular}

*Tabloda sadece istatistiksel olarak anlamll çıkan sonuçlar gösterilmiştir. 
Tablo IV: Öğrencilerin amaçlı aktivitelerle ilgili üniversitemizin imkanlarını yeterli bulma durumlarının dağılımı

\begin{tabular}{|l|c|c|c|c|c|c|}
\hline & \multicolumn{2}{|c}{ Yeterli } & \multicolumn{2}{c|}{ Yetersiz } & \multicolumn{2}{c|}{ Fikrim } \\
& \multicolumn{2}{|l}{ yok } \\
\hline & S & $\%$ & S & $\%$ & S & $\%$ \\
\hline Spor & 111 & 41,1 & 141 & 52,2 & 18 & 6,7 \\
\hline Okuma (kütüphane) & & & & & & \\
\hline Dergi, gazete & 73 & 27,0 & 49 & 18,1 & 148 & 54,9 \\
\hline Roman & 85 & 31,5 & 44 & 16,3 & 141 & 52,2 \\
\hline Çeşitli alanlarda kitap & 86 & 31,9 & 42 & 15,6 & 142 & 52,5 \\
\hline Canlı ( konser, panel, şiir dinletisi, tiyatro, spor & 88 & 32,6 & 156 & 58,2 & 26 & 9,2 \\
müsabakaları vb. ) aktiviteler & & & & & & \\
\hline Müzik aleti çalma, solo, koro, orkestraya & 62 & 23,0 & 176 & 65,2 & 32 & 11,8 \\
katılma & & & & & & \\
\hline Beceri gerektiren el işi ve sanatla uğraşma & 52 & 19,3 & 188 & 69,6 & 30 & 11,1 \\
\hline Dernek, klüp faaliyetleri & 161 & 59,6 & 88 & 32,6 & 21 & 7,8 \\
\hline Gezi & 109 & 40,4 & 142 & 52,6 & 19 & 7,0 \\
\hline Kişisel gelişimi sağlayıcı kurslar & 89 & 33,0 & 160 & 59,3 & 21 & 7,7 \\
\hline
\end{tabular}

